\title{
Vehnän kasvinsuojelun muuttuneet haasteet
}

\author{
Marja Jalli, Erja Huusela-Veistola, Heikki Jalli ja Ulla Heinonen \\ MTT Kasvinsuojelu, 31600 Jokioinen, etunimi.sukunimi@mtt.fi
}

\section{Tiivistelmä}

Viljelykierto, muokkauksen intensiteetti sekä sääolot vaikuttavat niin kasvitautien, tuhoeläinten kuin rikkakasvien runsauteen. Tekijöillä on myös yhdysvaikutuksia ja ne kohdistuvat eri tavoin eri kasvintuhoojiin. Suorakylvössä muokkauksen kasvintuhoojia vähentävä vaikutus jää pois, jolloin monipuolisen viljelykierron merkitys korostuu. Sääolot lopulta määräävät sen, mitkä kasvinsuojeluongelmat kunakin kasvukautena realisoituvat.

Kevätvehnän viljelyala oli vuosina 2006 ja 2007 noin 170000 ha, ja siitä noin $10 \%$ oli suorakylvettyä. Vehnän viljelyssä tapahtuneet muutokset heijastuvat kasvinsuojeluun. Muokkauksen keventyessä merkittävin kasvitautiriskiä lisäävä tekijä on maan pinnalle jäänyt olkijäte. Muuttuvat ympäristöolosuhteet voivat tuoda esille aiemmin satunnaisemmin esiintyneitä taudinaiheuttajia, kuten kevätvehnällä yleistyneen vehnänlehtilaikun. Yksipuolisessa vehnänviljelyssä ongelmia aiheuttavat hesseninsääski, tähkäsääski ja vehnäsääski. Samat lajit voivat lisääntyä suorakylvössä, koska ne hyötyvät muokkaamattomuudesta. Kasvinesteitä imevien hyönteisten runsastumiseen liittyy riski virustautien leviämiselle. Rikkakasvien torjunnassa kasvinvuorotuksen vaikutus on suurinta, kun käytettävissä on mahdollisimman suuri valikoima erilaisia kasveja. Tällöin kasvien kilpailukyky ja mahdolliset torjuntatoimet vaihtelevat vuosittain; tiettyihin oloihin sopeutuneet rikkakasvit eivät pääse lisääntymään eikä herbisidiresistenssiä synny. Juolavehnä on sopeutunut yksipuoliseen viljanviljelyyn ja se kilpailee tehokkaasti vehnäkasvustossa.

MTT:Ilä Jokioisilla vuosina 2001-2007 toteutetuissa suorakylvön kasvinsuojeluhankkeissa tutkittiin suorakylvön vaikutusta kasvintuhoojiin sekä selvitettiin kasvintuhoojien hallintakeinoja. Viljelykiertokokeen tulosten pohjalta suorakylvö lisää kevätvehnän lehtilaikkutautiriskiä erityisesti kasvukauden alkuvaiheessa, jos esikasvina on vehnä. Kasvukauden sääolot sekä kasvuston kunto vaikuttavat merkittävästi lehtilaikkutautien etenemiseen alkutartunnan jälkeen. Taudinaiheuttajalle suotuissa olosuhteissa lehtilaikkutautien runsaus alkukasvukautena heijastuu loppukasvukaudella esiintyvään lehtilaikkutautien aiheuttaman vioituksen määrän̈. Vehnänlehtilaikkutaudinaiheuttajina Stagonospora nodorum ja Drechslera tritici repentis olivat kasvukaudella 2005 samanvertaiset ja niitä esiintyi tasaisesti kaikissa viljelykiertokokeen koejäsenissä.

Viirukaskaan (Psammotettix alienus) levittämän vehnän kääpiökasvuviroosin (Wheat dwarf virus, WDV) esiintyminen Suomessa varmistui kesällä 2004 otetuista syysvehnä- ja kaskasnäytteistä. Koska viruksen torjunta ei ole mahdollista, ainoa tapa on estää viruksen leviäminen viirukaskaan välityksellä. Syksystä 2005 lähtien tehtyjen kelta-ansaseurantojen perusteella viirukaskaat ovat yleisiä, mutta harvalukuisia. Tärkeimmät WDV:n riskitekijät ovat lämmin syksy ja syysvehnän aikainen kylvö. Myös suorakylvö ja kevytmuokkaus näyttävät lisäävän riskiä. Viirukaskaan torjuntatarpeen arviointi ja torjunnan ajankohta vaativat vielä tarkennuksia.

Monivuotisissa kenttäkokeissa todettiin rikkakasvilajiston muuttuvan suorakylvettäessä. Heinämäiset rikkakasvit lisääntyivät. Siemenrikkakasveista saunakukkaa esiintyi vain suorakylvettäessä, ja pihatähtimöä kynnettäessä. Linnunkaalia oli enemmän suorakylvöruuduilla kuin kyntöruuduilla. Suorakylvettäessä syksyisen glyfosaattikäsittelyn teho juolavehnään oli seuraavana kesänä yli 90 \%. Keväällä tehtyjen glyfosaattikäsittelyjen teho oli käsittelyvuonna samaa tasoa kuin syksyllä tehty käsittely.

Yksipuoliseen vehnän- ja viljanviljelyyn liittyy kasvinsuojeluriskejä. Lisäksi suorakylvöön siirtyminen ja maan muokkaamisen lopettaminen muuttavat kasvitautien, tuhoeläinten ja rikkakasvien elinmahdollisuuksia ja tuhoojalajiston rakennetta. Viljelytoimien lisäksi sääoloissa tapahtuvat muutokset heijastuvat tuhoeläinten ja kasvitautien runsauteen. Muutokseen vastataan riskinennakoinnilla sekä sovittamalla torjunta tarpeen mukaan.

\section{Asiasanat}

vehnä, kasvinsuojelu, kasvitaudit, tuhoeläimet, rikkakasvit, lehtilaikkutaudit, WDV, viirukaskas, juolavehnä, suorakylvö, viljelykierto, torjunta-aineet 


\section{Johdanto}

Viljelykierto, muokkauksen intensiteetti sekä sääolot vaikuttavat niin kasvitautien, tuhoeläinten kuin rikkakasvien runsauteen. Tekijöillä on myös yhdysvaikutuksia ja ne kohdistuvat eri tavoin eri kasvintuhoojiin. Kun lohkolla viljellään vuorovuosina eri viljelykasvia, tiettyyn viljelykasviin erikoistuneet kasvintuhoojat eivät pääse runsastumaan. Suorakylvössä muokkauksen kasvintuhoojia vähentävä vaikutus jää pois, joka luo mahdollisuuden tiettyjen kasvintuhoojien runsastumiselle. Sääolot lopulta määräävät sen, mitkä kasvinsuojeluongelmat kunakin kasvukautena realisoituvat.

Vehnän viljely painottuu Varsinais-Suomeen ja Uudellemaalle. Kevätvehnän viljelyala oli vuosina 2006 ja 2007 noin 170000 ha, ja siitä noin $10 \%$ oli suorakylvettyä. Syysvehnän viljely on kevätvehnän viljelyä selvästi vähäisempää. Syysvehnäala vaihtelee vuosittain paljon, koska loppukesän ja syksyn sääolot vaikuttavat kylvön onnistumiseen sekä talven ja kevään olosuhteet talvehtimisen onnistumiseen. Syksyllä 2006 syysvehnän kylvöala oli 38800 ha, josta 40 \% oli suorakylvettyä (Tike 2006, 2007).

Vehnän viljelyssä tapahtuneet muutokset heijastuvat kasvinsuojeluun. Kevätvehnän lehtilaikkutaudit ruskolaikku (Stagonospora nodorum) ja vehnänlehtilaikku (Drechslera tritici-repentis) talvehtivat joko siemenessä tai kasvijätteessä. Muokkauksen keventyessä merkittävin kasvitautiriskiä lisäävä tekijä on maan pinnalle jäänyt olkijäte. Viljelykierto sekä pellon kosteus- ja lämpöolosuhteet vaikuttavat kasvijätteessä säilyvän mikrobilajiston keskinäisiin voimasuhteisiin. Muuttuvat ympäristöolosuhteet voivat tuoda esille aiemmin harvinaisempia taudinaiheuttajia, kuten kevätvehnällä yleistyneen vehnänlehtilaikun.

Tuhoeläimet eivät ole yhtä spesifisiä isäntäkasvin suhteen kuin kasvitaudit. Vehnän tuhoeläimiä esiintyy myös muilla viljakasveilla. Yksipuolisessa vehnänviljelyssä ongelmia aiheuttavat hesseninsääski, tähkäsääski ja vehnäsääski ovat lajeja, joiden hallinnassa kasvinvuorotuksesta on hyötyä. Samat lajit voivat lisääntyä suorakylvössä, koska ne hyötyvät muokkaamattomuudesta. Viljakasvustoissa on viime vuosina esiintynyt kaskaiden, luteiden ja ripsiäisten aiheuttamia imentävioituksia, jotka sinällään eivät ole olleet sadon kannalta merkittäviä. Kasvinesteitä imevien hyönteisten runsastumiseen liittyy kuitenkin riski virustautien leviämiselle.

Siemenrikkakasvien taimettumiseen ja kasvumahdollisuuksiin vaikuttavat vahvasti kevään ja kesän sääolot, kuten myös viljelykasvien kasvuun ja torjunnan onnistumiseen. Kasvinvuorotuksen vaikutus on suurinta, kun käytettävissä on mahdollisimman suuri valikoima erilaisia kasveja: syysviljat, kevätviljat, öljykasvit, herne, nurmet, riviviljelykset, kesannot. Tällöin kasvien kilpailukyky ja mahdolliset torjuntatoimet vaihtelevat vuosittain, eivätkä tiettyihin oloihin sopeutuneet rikkakasvit pääse lisääntymään eikä herbisidiresistenssiä synny. Monivuotiset ja talvehtivat rikkakasvit kilpailevat viljelykasvien kanssa keväällä taimettuvia rikkakasveja voimakkaammin ja niiden torjuntakin vaatii erikoistoimia. Juolavehnä on sopeutunut yksipuoliseen viljanviljelyyn ja se kilpailee tehokkaasti vehnäkasvustossa.

\section{Aineisto ja menetelmät}

Tutkimusaineisto on osa MTT:llä toteutettua ja toteutuvaa laajempaa suorakylvötutkimusaineistoa, jota on vuosina 2002 - 2004 kerätty Kevätviljan suorakylvö - hankkeessa ja vuodesta 2005 lähtien Kasvinsuojelun tarpeet ja ratkaisut suorakylvetyllä pellolla (KaSu) - hankkeessa.

Lähdemateriaalina ovat monivuotiset kenttäkokeet sekä viljelijöiden ja tutkimusasemien pelloilta tehdyt seurannat ja laskennat. Kasvitautiaineisto on kerätty vuonna 2005 perustetusta monivuotisesta kevätvehnän viljelykiertokokeesta, jossa on kevätvehnän monokulttuuria vuodesta 2003 lähtien. Kokeessa tutkitaan muokkausmenetelmän (kyntö, suorakylvö) sekä esikasvin (kevätvehnä, ohra, rypsi, herne) vaikutusta kevätvehnän kasvinsuojelutarpeeseen.

Tuhohyönteisten esiintymistä syysvehnäkasvustoissa seurattiin KaSu-hankkeen kenttäkokeissa Jokioisilla, Kemira GrowHow:n koetilalla Vihdissä, Västankvarnin koetilalla Inkoossa sekä NSL:n neuvojien toimesta viljelijöiden pelloilla. Tarkkailussa käytettiin keltaisia liimapyydyksiä (puolikas Catch-it kelta-ansa, koko $9.5 \mathrm{~cm}$ x $32 \mathrm{~cm}$ ). Seuranta tehtiin keväällä touko-kesäkuussa sekä syksyllä elolokakuussa.

Syysmuokkausten, eli kynnön ja kultivoinnin, tai muokkaamattomuuden sekä glyfosaattikäsittelyajankohdan vaikutusta kevätvehnäsatoon sekä juolavehnän kasvuun tutkittiin vuosina 2005-2007 Jokioisilla, Piikkiössä ja Ylistarossa tehdyissä neljässä kenttäkokeessa. Rikkakasvien taimettumista ja lajiston muutoksia kevätviljakasvustossa on vuodesta 2001 lähtien tutkittu Jokioisten koekentällä. Kokeessa on sekä muokkaamaton että muokattu kasvuympäristö. Kasvilajeina ovat olleet kevätvehnä, ohra ja kaura. Rikkakasvilajiston muutoksia on tutkittu vuosittaisella taimettuneiden rikkakasvien laskennalla. 


\section{Tulokset ja tulostentarkastelu}

\section{Kasvitaudit}

Jokioisten viljelykiertokokeessa tutkittiin muokkausmenetelmän ja viljelykierron vaikutusta kevätvehnän kasvitauteihin. Kasvitauteja esiintyi jokaisena tutkimusvuotena kaikissa viljelykiertokokeen koeruuduissa. Merkittävimmät kasvitaudit olivat ruskolaikku (Stagonospora nodorum) sekä vehnänlehtilaikku (Drechslera tritici-repentis). Koska vehnän lehtilaikkutaudit esiintyvät usein yhdessä ja niiden oireet ovat hyvin samankaltaiset, havainnoitiin kahden taudinaiheuttajan runsaus kasvustosta yhtenä muuttujana 'lehtilaikkutauti - \% '. Kevätvehnän ilmalevintäisiä kasvitauteja härmää (Blumeria graminis) ja ruskearuostetta (Puccinia recondita f. sp. tritici) esiintyi kokeessa hyvin vähän.

Ensimmäiset lehtilaikkutautihavainnot tehtiin korrenkasvun alussa (BBCH 31). Vuosien välinen vaihtelu lehtilaikkutautien määrässä oli alkukesällä pientä. Lehtilaikkutaudit peittivät korkeintaan $5 \%$ kasvuston pinta-alasta. Maitotuleentumisasteella (BBCH 75) lehtilaikkutautien esiintymisrunsaus vaihteli vuosittain. Voimakkain tartunta oli kasvukautena 2007, jolloin maksimissaan $30 \%$ kevätvehnäkasvustosta oli lehtilaikkutautien peitossa. Alhaisin tartunta oli vuonna 2006, jolloin lehtilaikkutaudit tuhosivat korkeintaan $3 \%$ kasvustosta.

Sekä muokkausmenetelmä että esikasvi vaikuttivat lehtilaikkutautien esiintymiseen. Vuosina 2005 ja 2007 esikasvilla oli merkitsevä $(\mathrm{P}<0,001)$ vaikutus lehtilaikkutautien esiintymiseen jo korrenkasvun alkuvaiheessa (BBCH 31). Suorakylvetyissä koejäsenissä sekä vehnä että ohra esikasveina lisäsivät laikkutautien määrää. Kaikkina tutkimusvuosina korrenkasvuvaiheen lehtilaikkutartunta oli runsain suorakylvetyissä kevätvehnäruuduissa.

Tutkimusvuonna 2005 sekä muokkausmenetelmä että esikasvi vaikuttivat merkitsevästi lehtilaikkutautien esiintymiseen maitotuleentumisasteella $(\mathrm{P}<0,0001)$. Lehtilaikkutartunta oli voimakkain suorakylvetyissä vehnän monokulttuuriruuduissa. Alhaisin lehtilaikkutartunta oli kynnetyissä koeruuduissa, joiden esikasvina oli ohra tai rypsi. Kuivana ja lämpimänä kasvukautena 2006 lehtilaikkutautien kokonaismäärät olivat alhaiset eikä eri käsittelyjen välillä ollut merkitseviä eroja. Kasvukauden 2007 sateinen heinäkuu suosi lehtilaikkutautien etenemistä. Muokkauksen vaikutus lehtilaikkutautien etenemiseen heikkeni kasvukauden edetessä, ja maitotuleentumisasteella ainoastaan esikasvilla oli merkitsevä vaikutus taudinaiheuttajien määrään $(\mathrm{P}<0,0001)$. Esikasvivaikutus korostui suorakylvettäessä. Kynnetyissä koejäsenissä lehtilaikkutartunta oli alhaisin, kun esikasvina oli ohra tai herne. Suorakylvettäessä alhaisin lehtilaikkutartunta oli koeruuduissa, joiden esikasvina oli herne (Kuva 1).

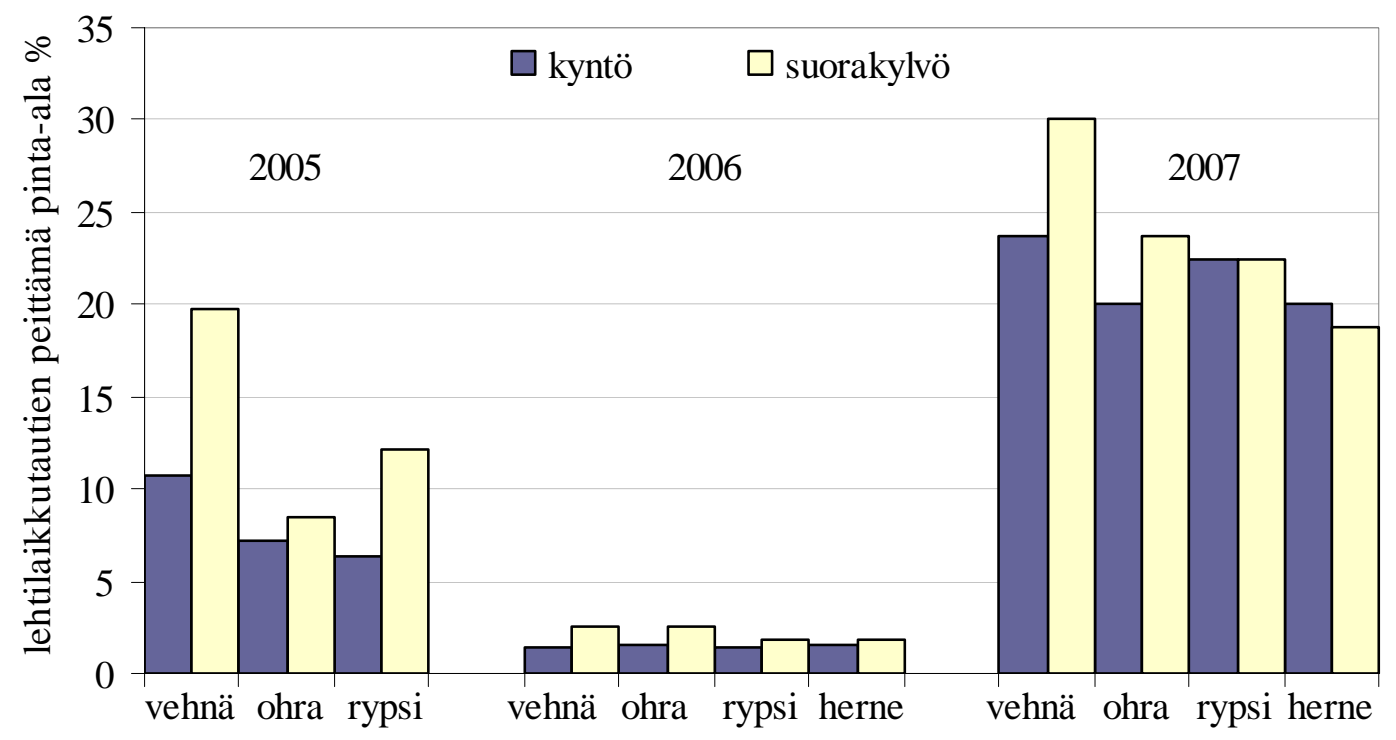

Kuva 1. Kevätvehnän lehtilaikkutautien esiintyminen maitotuleentumisasteella kynnössä ja suorakylvössä, kun esikasvina on vehnä, ohra, rypsi tai herne. Jokioinen 2005 - 2007. 
Kasvukautena 2005 kevätvehnäruuduilta määritettiin lehtilaikkutautien aiheuttajat. Kasvustosta kerättiin oireiset lehtinäytteet tähkälletulo- ja maitotuleentumisvaiheessa ja niiden lajisto määritettiin silmämääräisesti, V8-kasvatusmaljoilla sekä PCR-diagnostiikalla. Taudinaiheuttajat tunnistettiin 16 näytteestä koejäsentä kohti. Yksi näyte koostui neljästä tautioireisesta lehdestä.

Tähkälletulovaiheessa oireisia lehtiä ei ollut kaikissa koejäsenissä riittävästi 16 näytteen muodostamiseksi. Kyntöruuduista, joissa ohra tai rypsi oli esikasvina, saatiin muodostettua vain 6 näytettä. Oireet olivat myös huomattavasti pienempiä kuin myöhemmin kasvukaudella. Tähkälletulovaiheessa kerätyissä näytteissä $D$. tritici repentis tai S. nodorum - sieni selittivät joko yksin tai yhdessä vähintään 60 \%, ja maitotuleentumisvaiheessa $100 \%$ esiintyvistä oireista. Sienilajien esiintymisessä ei ollut eroa eri muokkausten tai esikasvien välillä. Molempia taudinaiheuttajia esiintyi tasaisesti kaikissa koejäsenissä.

Vuosina 2005 - 2007 Jokioisilla toteutetun viljelykiertokokeen tulosten pohjalta suorakylvö lisää kevätvehnän lehtilaikkutautiriskiä erityisesti kasvukauden alkuvaiheessa, jos esikasvina on vehnä. Kasvukauden sääolot sekä kasvuston kunto vaikuttavat merkittävästi lehtilaikkutautien etenemiseen alkutartunnan jälkeen. Taudinaiheuttajalle suotuissa olosuhteissa lehtilaikkutautien runsaus alkukasvukautena heijastuu loppukasvukaudella esiintyvään lehtilaikkutautien aiheuttaman vioituksen määrään.

Vehnänlehtilaikkutaudinaiheuttajina S. nodorum ja D. tritici repentis olivat kasvukaudella 2005 samanvertaiset ja niitä esiintyi tasaisesti kaikissa viljelykiertokokeen koejäsenissä. Taudinaiheuttajien erottaminen visuaalisesti ei ole luotettavaa vaan tunnistaminen on tehtävä joko maljaamalla tai PCRdiagnostiikalla.

\section{Tuhoeläimet}

Viirukaskaan (Psammotettix alienus) levittämän vehnän kääpiökasvuviroosin (Wheat dwarf virus, WDV) esiintyminen Suomessa varmistui kesällä 2004 otetuista syysvehnä- ja kaskasnäytteistä (Huusela-Veistola \& Lemmetty 2005, Lemmetty \& Huusela-Veistola 2005). Epäilyksiä taudin esiintymisestä on ollut ennenkin, mutta taudinaiheuttajaa ei ole aiemmin määritetty. Vehnän kääpiökasvuviroosin tyypillinen oire on vehnän kääpiöityminen ja kellastuminen. Tuhot esiintyvät usein laikkuina tai pellon reunaosissa (Kuva 2).

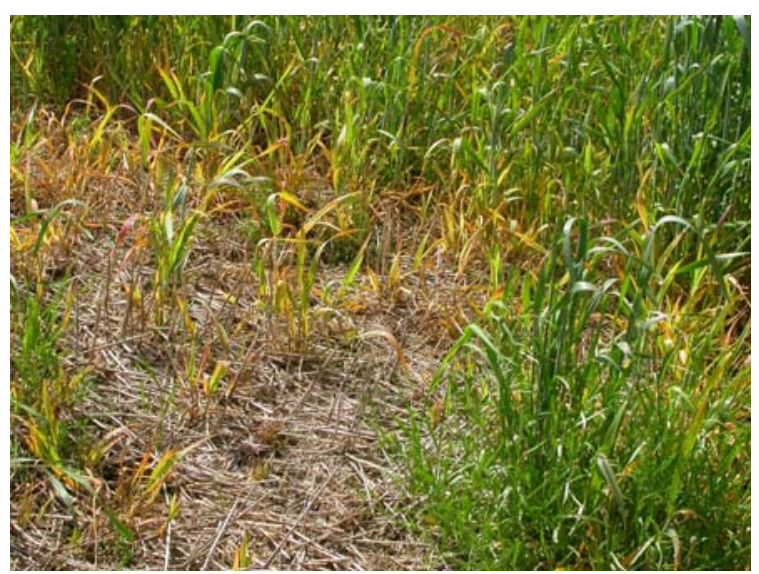

Kuva 2. Vehnän kääpiökasvuviroosia syysvehnässä.

Vehnän kääpiökasvuviruksella on useita heinäkasveihin kuuluvia isäntäkasveja. Virus siirtyy kasvista toiseen ainoastaan vektorin eli viirukaskaan välityksellä. WDV-tartunnan leviäminen on kaksivaiheinen: Viirukaskaan syyssukupolven aikuiset levittävät viruksen syysvehnän oraisiin kylvövuonna (primaaritartunta). Viirukaskas talvehtii munana ja kuoriutuvat toukat levittävät virusta viroottisista kasveista viereisiin kasveihin (sekundaaritartunta). WDV-tartunta edellyttää virusta siirtävien kaskaiden ja syysvehnän tietyn kasvuvaiheen samanaikaista esiintymistä.

Koska viruksen torjunta ei ole mahdollista, ainoa tapa on estää viruksen leviäminen viirukaskaan välityksellä. Viirukaskaan esiintymistä on seurattu kenttäkokeissa ja viljelijöiden pelloilla syksystä 2005 lähtien. Seurantojen perusteella viirukaskaat ovat harvalukuisia, mutta niitä esiintyy syysvehnäpelloilla jopa lokakuulle saakka (Kuva 3). Syksyllä viirukaskaiden esiintyminen ajoittuu samaan aikaan kahukärpästen esiintymisen kanssa. Kummankin lajin esiintymishuippu osuu syyskuun alkuun eli aikaisin kylvet- 
tyjen syyviljojen orastumisaikaan. Vaikka syksyllä 2006 viirukaskaita oli liikkeellä runsaasti, kesällä 2007 vehnän kääpiökasvuviroosia tavattiin vain satunnaisesti. Keväällä ensimmäisiä aikuisia viirukaskaita havaittiin touko-kesäkuun vaihteessa ja esiintymishuippu ajoittui kesäkuun puoliväliin.

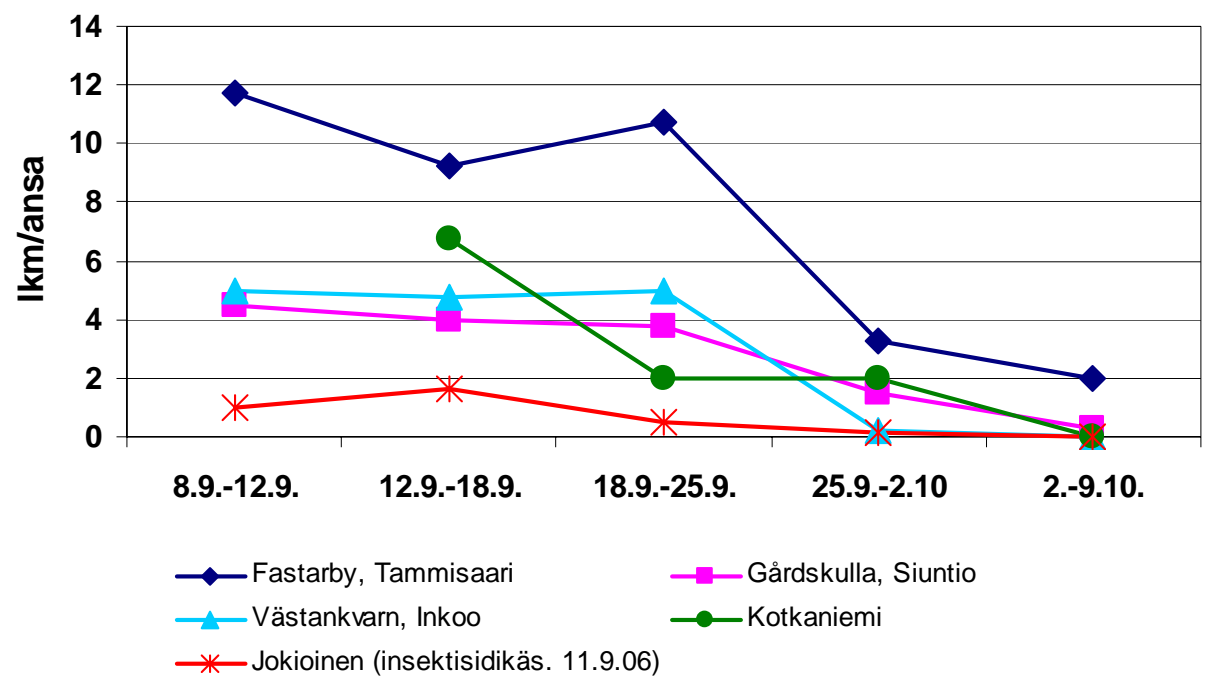

Kuva 3. Viirukaskaan esiintyminen kelta-ansaseurannoissa syksyllä 2006. Jokioisilla tehty insektsidikäsittely 11.9.2006.

WDV:n torjuntakokeita on tehty Jokioisilla, Inkoossa ja Vihdissä, mutta niistä saadut tulokset ovat jääneet vähäiseksi, koska viirukaskaan esiintymisestä huolimatta koeruuduissa ei ole esiintynyt vehnän kääpiökasvuvirusta. WDV:n esiintymisen vaihtelu hankaloittaa hallintamenetelmien kehittämistä ja aiheuttaa epävarmuutta ennusteisiin. Vaikka tiettyjä riskitekijöitä esiintyisikin, viruksen leviäminen on monimutkainen prosessi, joka vaatii virustartuntalähteen, virusta siirtävien kaskaiden ja sopivassa kasvuvaiheessa (ennen 1-solmuvaihetta) olevan syysvehnäkasvuston samanaikaisen esiintymisen.

Suomessa ja Ruotsissa saatujen kokemusten mukaan tärkeimmät WDV:n riskitekijät ovat lämmin syksy ja syysvehnän aikainen kylvö. Myös suorakylvö ja kevytmuokkaus näyttävät lisäävän riskiä. Jos lohkolla on esiintynyt WDV-oireita, vanha vehnän sänki on syytä rikkoa muokkauksella. Pellon pintaan jäävä kasvijäte ja syksyllä versova jääntivilja näyttävät myös lisäävän riskiä.

Edellä esitettyjen seurantatulosten ja aiempien tutkimusten perusteella (Raatikainen \& Vasarainen julkaisematon) viirukaskas on yleinen, mutta ei kovin runsaslukuinen viljapelloilla ja nurmissa elävä kaskas. Vehnän kääpiökasvuviroosin hallinta vaatii edelleen viirukaskaan tarkkailun ja ennustemenetelmien kehittämistä. Keltaiset liimapyydykset eivät välttämättä ole tehokkain viirukaskaan seurantatapa, mutta ne ovat käteviä käyttää ja sopivat samalla kahukärpäsen tarkkailuun. Viirukaskaan torjuntatarpeen arviointi ja torjunnan ajankohta vaativat vielä tarkennuksia. Tällä hetkellä suosituksena on syystorjunta kahukärpästorjunnan yhteydessä. Ruotsissa on saatu hyviä tuloksia myös viirukaskaan toukkien kevättorjunnasta, jonka avulla vähennetään WDV:n sekundaaritartuntaa.

\section{Rikkakasvit}

Jokioisilla, Piikkiössä ja Ylistarossa vuosina 2004-2006 tehdyissä neljässä kenttäkokeessa juolavehnäsaastunta pienensi käsittelemättömän kynnetyn koejäsenen kevätvehnäsatoa 1200 kg hehtaarilla verrattuna kynnettyyn koejäseneen, joka sai glyfosaattikäsittelyn syksyllä (3600 kg/ha). Sängelle ruiskutetun glyfosaatin jälkeen tehdyn kultivaattorikäsittelyn vehnäsato oli $3250 \mathrm{~kg} / \mathrm{ha}$. Suorakylvetystä ruiskuttamattomasta koejäsenestä ei saatu kevätvehnäsatoa lainkaan. Syksyn sängelle tehdyn glyfosaattikäsittelyn jälkeen sato oli $2550 \mathrm{~kg} / \mathrm{ha}$ ja suurin suorakylvövehnäsato (3 $100 \mathrm{~kg} / \mathrm{ha}$ ) saatiin torjuttaessa juolavehnä ennen kylvöä. Suorakylvön jälkeen glyfosaattikäsitellyn vehnän sato oli 2825 kg/ha.

Ruiskuttamattomilla kynnetyillä ruuduilla juolavehnää kasvoi syksyllä keskimäärin $1230 \mathrm{~kg}$ kg/ha. Glyfosaattikäsiteltyjen koejäsenten juolavehnäsato vaihteli välillä 44 - 550 kg/ha. Käsittelemättömillä suorakylvöruuduilla juolavehnää kasvoi syksyllä keskimäärin 4070 kg/ha (Kuva 4). 


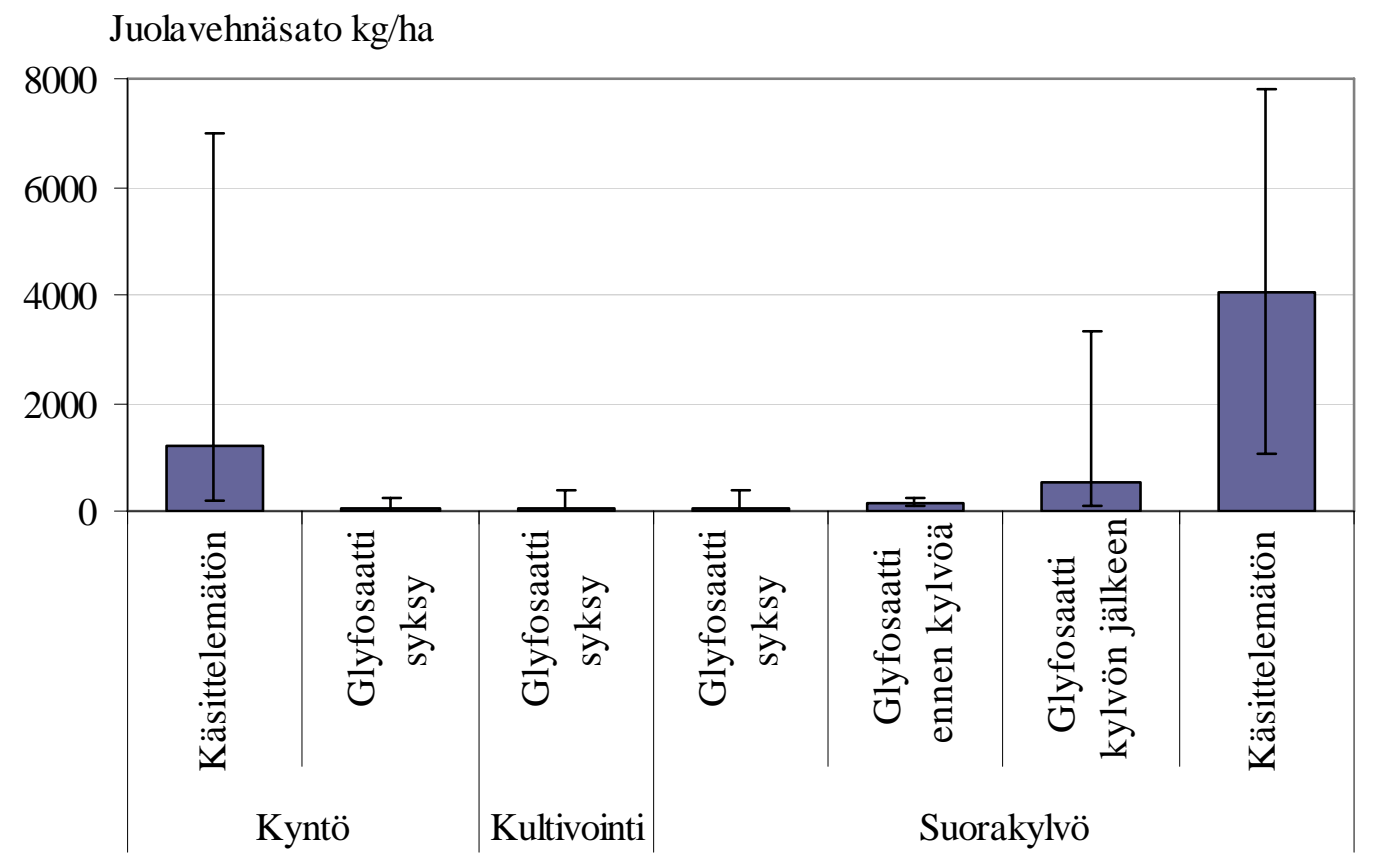

Kuva 4. Keskimääräinen juolavehnäsato syksyllä kevätvehnäkasvustossa eri syysmuokkausten tai muokkaamattomuuden ja glyfosaattikäsittelyjen jälkeen. Yhteensä neljä koetta Jokioisilla, Piikkiössä ja Ylistarossa

Vuosina 2001-2007 Jokioisten pitkäaikaisella muokkauskoekentällä jouduttiin heinämäisiä rikkakasveja, kuten timoteitä, nurmikkoja, puntarpäitä ja lauhoja, torjumaan kahdesti glyfosaattiruiskutuksin. Koealalla ei koko koejakson aikana kasvanut pelto-ohdaketta, -valvattia tai juolavehnää. Siemenrikkakasvien kokonaistaimettumiseen vaikuttivat eniten kasvukauden ja muokkausmenetelmän yhdysvaikutus ja kasvukausi $(\mathrm{P}<0,001)$. Muokkausmenetelmien välillä ero oli hyvin merkitsevä; rikkayrttejä taimettui koejaksolla enemmän suorakylvettäessä.

Siemenrikkakasvien lajisto muuttui jatkettaessa suorakylvöä. Peltomataran taimettumiseen vaikuttivat eniten kasvukausi ja kasvukauden ja kylvömenetelmän yhdysvaikutus $(\mathrm{P}<0,001)$, kylvömenetelmien välillä ei eroa ollut. Saunakukkaa esiintyi vain suorakylvettäessä, ja pihatähtimöä kynnettäessä. Linnunkaalia oli enemmän suorakylvöruuduilla kuin kyntöruuduilla $(\mathrm{P}<0,001)$. Punapeippi ja jauhosavikka olivat yleisempiä kyntöruuduilla $(\mathrm{P}<0,001)$.

Vuosina 2005 - 2007 toteutettujen tutkimusten mukaan juolavehnä on sopeutunut yksipuoliseen viljanviljelyyn, ja se kilpailee tehokkaasti vehnäkasvustossa. Kasvukaudella vehnästä voi torjua juolavehnää Monitor-valmisteella, mutta tärkeimpiä valmisteita juolavehnän torjuntaan ovat erilaiset glyfosaattivalmisteet. Perinteisesti juolavehnäntorjunta glyfosaatilla tehdään sänkikäsittelynä syksyllä ennen syysmuokkausta. Syksyisen glyfosaattikäsittelyn teho juolavehnään on seuraavana kesänä yli 90 \%. Keväällä ennen kylvöä tehty glyfosaattikäsittely voi olla liian aikainen juolavehnän kehityksen kannalta. Kylvö leikkaavavantaisella kylvökoneella katkoo juolavehnän juurakkoa niin, etteivät kaikki juurakon osat saa torjunta-ainetta kylvön jälkeen tehdyssä käsittelyssä, ja teho saattaa jäädä huonoksi.

\section{Johtopäätökset}

MTT Kasvinsuojelulla vuosina 2001 - 2007 tehtyjen tutkimusten perusteella yksipuoliseen vehnän- ja viljanviljelyyn liittyy kasvinsuojeluriskejä. Lisäksi suorakylvöön siirtyminen ja maan muokkaamisen lopettaminen muuttavat kasvitautien, tuhoeläinten ja rikkakasvien elinmahdollisuuksia ja tuhoojalajiston rakennetta.

Viljelytoimien lisäksi sääoloissa tapahtuvat muutokset heijastuvat tuhoeläinten ja kasvitautien runsauteen. Tuhohyönteisillä on yleisesti ominaisuuksia, joista on etua ilmastonmuutokseen sopeutumisessa. Monet tuhoeläinlajit ovat hyviä leviämään ja nopeita lisääntymään. Kasvukauden olosuhteiden lisäksi onnistuneella talvehtimisella on ratkaiseva merkitys kasvintuhoojien menestymiseen. Yleisesti ilmaston 
muutoksen vaikutukset tuhohyönteisiin ja kasvitauteihin ilmenevät esiintymisalueiden, esiintymisajankohdan ja runsauden muutoksina. Rikkakasveista monivuotiset heinämäiset lajit hyötyvät eniten pitenevästä kasvukaudesta. Kasvintuhoojien tarkkailun merkitys korostuu. Muutokseen vastataan riskinennakoinnilla sekä sovittamalla torjunta tarpeen mukaan.

\section{Kiitokset}

Kiitokset kaikille kelta-ansaseurantaan ja havainnointiin osallistuneille.

\section{Kirjallisuus}

Huusela-Veistola, E. \& Lemmetty, A. 2005. Viirukaskaan levittämää vehnän kääpiökasvuvirusta Suomessa. Kasvinsuojelulehti s.8-10. vol. 38 nro 1/2005.

Lemmetty, A. \& Huusela-Veistola, E. 2005. First report of wheat dwarf virus in winter wheat in Finland. Plant disease p. 912 vol. 89 nro 8/2005. 